\title{
Variety, Volatility, Intensity: Understanding Key Characteristics of Individual Learner Differences
}

\section{Nathan T. Ducker \\ Miyazaki Municipal University}

\section{Reference Data:}

Ducker, N. T. (2020). Variety, volatility, intensity: Understanding key characteristics of individual learner differences. In P. Clements, A. Krause, \& R. Gentry (Eds.), Teacher efficacy, learner agency. Tokyo: JALT. https://doi.org/10.37546/JALTPCP2019-10

Individual Learner Differences (ILDs), such as motivation, anxiety, and willingness to communicate, account for varying rates and extents of successful $L 2$ learning. Traditional quantitative approaches to studying ILDs render constructs to a one-size-fits-all explanation of factors and relationships that affect learning outcomes. A Complex Dynamic Systems Theory approach to studying ILDs rectifies this situation and supports teachers by investigating the interrelated, variable, and situated aspects of ILDs. In this study, students selected ILDs that most impacted their partner's classroom participation. They then used idiodynamic methodology, a relatively new research method, to elicit factors that influenced changes to their partner's ILDs in class. Unexpected constructs, such as concentration, happiness, and anger, were chosen. Within those ILDs, a wide range of volatility and intensity of change was reported. Internal-, linguistic-, topic-, social-, and stage-of-the taskfactors initiated chains-of-events leading to variations in ILD constructs. Implications for pedagogy and further research are discussed.

第二言語学習者の学習速度や到達しべルの違いは、モチベーション、不安感 話をしたいという意欲の様な「学習者の個人 差に起因する。徒来の個人差を研究する定量的アプローチでは、学習結果汇影響を与える要因や関連性についてて画一的な

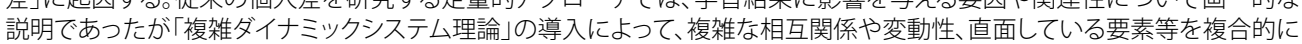
調查できる様になった。本研究において、学生は、活動相手の從業参加に最も影響を与ええた個人差の要素を自身で選択した 後、その要因を導き出す為に、新しい研究法である「イデイオダイナミ゙ク法をを使用した。その結果、集中力、幸福感怒りの様 な想定外の要素が選択され、変化の頻度や起伏の浮き沈みが広範囲に及ぶ事も判明した。内面的、言語的・トヒックやや社会的 な要素、タスクの進度状況等の要素が一連の出来事に起因し、学習者の様々な個人差の構成に影響を与えた。本論文では教 授法や更なる研究結果も述べる。
Tnderstanding social, cognitive, and affective factors that account for variations in the extent and speed of each learner's $\mathrm{L} 2$ development can greatly enhance teacher effectiveness; for example, educators want to know under what conditions a learner's motivation and commitment to class/homework are reflected in linguistic development.

In addition to effort, some learners may initially possess higher levels of intelligence, aptitude, and memory; while others are more amenable to risk-taking, relationship building, and other emotional pre-requisites for engaging in $\mathrm{L} 2$ communication. These individual learner differences (ILDs) are often described as enduring traits that teachers can "tap into" as resources. However, this perspective may unfairly limit efforts to develop learners' capabilities and lead to confusion when trait-like descriptions of ILDs are not reflected in learners' behaviours or L2 development. For example, teachers may make opportunities for quieter individuals by gently reigning in extroverted classmates, yet quiet learners may prefer learning by listening.

Deeper insights into what drives each learner and how learners adjust to classroom conditions are invaluable for teachers. One question that teachers need to consider is "what ILDs do students believe inhibit and facilitate their own successful L2 development in the classroom?" Therefore, I asked students to work with a partner to co-research factors that impacted their classroom participation.

\section{Literature Concerning ILDs \\ ILD Categories}

Ellis (2004) identified four categories of ILDs that teachers and learners can manage and manipulate to facilitate learning:

1. Abilities: differences in intelligence, aptitude, and memory mean some learners may "get" the points of a lesson more quickly and with less effort than others.

2. Propensities: some learners are more amenable to in-class activities or sustain greater learning efforts due to factors such as willingness to communicate (WTC) or motivation. 
3. Cognition: learners who value language study and agree with their teacher's pedagogical approach may pay more attention and try harder.

4. Actions: some learners develop strategies to nurture good study habits and/or overcome hurdles.

Ellis (2004) stated that the two clearest determiners of L2 success are aptitude and motivation, while Ushioda and Dörnyei (2009) claimed the same for motivation.

\section{ILDs and Pedagogy}

Understanding ILDs may help explain learners' behaviours and related L2 success while providing information for improving pedagogical practices. For instance, Robinson (2002) posited that learners who display greater aptitude for acting on on-line feedback, such as recasts, can do so due to the effective functioning of working memory for contingent speech and an ability to notice the difference between their output and the given feedback, which Ranta (2008) believed can be improved through remediation. Concerning cognition, learner beliefs should align with the type of studying that takes places; for example, Aubrey (2010) found that Japanese learners who reported greater levels of belief in the efficacy of communicative language teaching communicated more in class.

Strategy use may be the most clearly actionable field of ILD research. Oxford and Amerstorfer (2018) defined strategies as mental actions that involve cognitive, social, affective, motivational, and metacognitive functions to complete learning tasks and improve language performance. Strategies can meet needs in specific contexts; for example, Siegel (2015) explored listening strategy instruction, and Crawford (2015) focused on notetaking strategies. The interrelatedness of ILDs in strategy instruction must be acknowledged; for notetaking, students must believe in the utility of notetaking and be motivated to do so, while the quality/quantity of notes taken depends on learners simultaneously engaging various listening, noticing, evaluating, and writing skills.

There is growing agreement that ILDs develop and can be modified (Pawlak, 2017), but the extent, focus, and timing of effective interventions varies. Concerning WTC, Matsuoka (2015) described the development of long-term, trait-WTC through real-life L2 exposure; in the medium-term, MacIntyre \& Doucette (2009) suggested learners develop strategies to manage communication difficulties; while in the classroom, Kang (2005) recommended a wide range of teacher-led interventions to facilitate interaction. Accordingly, Gregersen and MacIntyre (2014) suggested teachers develop a reactive approach that is sensitive to individuals' needs and the dynamic classroom situation.

\section{Misunderstood Nature of ILDs}

False dichotomies may confuse teachers when choosing approaches to respond to learners' individuality. Ellis (2008) noted a lack of unifying ILD framework, which means they are often studied as unrelated, discrete, monolithic entities. Moreover, Dörnyei (2009) argued that, despite a long-held belief that motivation was the most prevalent affective ILD and the most prevalent cognitive ILD was aptitude, they are deeply intertwined aspects of the same system.

Additionally, many ILDs have typically been seen as inherent learner traits (Dörnyei, 2017); for example, some learners may be labelled as more anxious and some as more motivated. However, similar factors, such as motivation to attend class (for credits) and motivation to participate in class (for linguistic development) are different things (Dörnyei, 2001; 2005). Furthermore, Macintyre and Legatto (2011) studied variations in WTC on a per-second timescale; confirming that ILDs have both a trait-like and a situated, variable aspect.

\section{A Complex Dynamic Systems Approach to ILD Research}

With a growing acceptance of the interrelated and situated nature of ILDs (Dörnyei, 2017) and recognition of the limitations of self-report questionnaires and statistical models to undercover the relationship between ILDs and language learning (Ellis, 2004), Larsen-Freeman's (2015) complex dynamic systems theory approach (CDST) to ILDs offers opportunities for researchers in the following different ways:

1. Allowing for variations in an individual's ILDs rather than assuming they are unvarying traits.

2. Acknowledging various time scales such as trait-characteristics, in-class behaviours, and reactions to specific moments-in-time.

3. Examining interrelated relationships between variables rather than assuming variables are discrete items.

4. Accepting the highly unpredictable nature, extent, and timing of cause and effect relationships.

5. Acknowledging that the state of ILDs are linked to prior events and states, undergo continuous evolution, and are susceptible to feedback in the system.

6. Affirming the context dependent nature of ILDs.

MacIntyre, Dörnyei, and Henry (2015) further proposed that ILDs are multi-causal in nature, meaning changes in ILDs are impacted by multiple factors. They additionally 
point out that ILDs undergo "soft assembly." Juxtaposed to the idea of learners'

behaviours being hard-wired, this means that learner behaviours are unpredictable; even slight variations in similar combinations of factors may lead to important differences in a learner's behaviours.

\section{The Study}

\section{Research Questions}

Given that ILDs are individualized, complex, variable and continuously developing, I wanted to know how students perceived ILDs rather than researching ILDs that previous research indicated as important. The following questions were investigated:

1. Which ILDs did students perceive to be important for them in-class?

2. What is the relationship between learners' in-class and trait-like experiences of this ILD?

3. Is the ILD volatile or stable in class?

4. What factors influence this ILD?

5. Are these factors under the locus of control of the learner or subject to external influences?

\section{Participants and Setting}

I carried out the study as part of the regular curriculum in an English as a medium of instruction seminar class in a university in Japan. The class is student-centered and involves discussions, group activities, and various individual and group presentations. Data from two classes with nine members are reported. The students' English proficiency ranged from high (CEFR C1) to intermediate (CEFR B1).

\section{Tools: Idiodynamic Software}

Macintyre and Legatto (2011) developed a video playback software that allowed students to register changes in various psychometric constructs. I commissioned and trialed an adjusted version of the software, using an online freelancing agency. The software incorporates a video player with "up" and "down" ratings buttons at the bottom of the video screen. During playback, participants can rate their psychometric status from -10 to +10 as they undergo changes during an activity. If the student does not register a score, the rating returns to zero after a 2.5 second delay. The software has a hold function that maintains a consistent rating if there is no change in status. The subject's ratings and time-stamp data are returned in a Microsoft Excel table and chart.

\section{Methodology}

The study took place across two scheduled 90-minute lessons with follow-up homework. First, students discussed a translation issues worksheet covering cultural transference, pragmatics, idiomatic differences, discourse, and linguistic problems. I clarified ambiguous or difficult points on the worksheet but did not join the small-group discussions. I recorded each group concurrently with separate video cameras, and I stopped the cameras at 15-minute intervals to provide six shorter recordings for review. To provide space for recording equipment, one discussion took place in an adjacent classroom, and I alternated between classrooms.

After the discussion, I introduced the students to a range of ability-, propensity-, cognitive-, and action-based ILD factors that may hinder or enhance successful communication. For homework, students self-appointed a partner from another group and interviewed them. Interview steps were:

- One: negotiate which video excerpt provided the most revealing insights into the interviewee's in-class thoughts and emotions.

- Two: negotiate which ILD most influenced (enabled or hindered) the interviewee's discussion participation.

- Three: use an ILD questionnaire tool to measure the interviewee's trait-like aspect of the ILD, then confirm the appropriacy of this score on the basis of: (10) extremely high, ( 8 or 9) high, (6 or 7) above average, (5) average, (4 or 3) below average, ( 2 or 1$)$ low, (0) extremely low.

- Four: use idiodynamic software to record in-class ILD ratings.

- Five: use the idiodynamic ratings and video playback to elicit factors that impacted their ILD and discussion participation.

Post-interview, the learners reversed roles and repeated the process. Finally, learners used the data from the questionnaire tool, the idiodynamic software, and interview to create a chart for the selected ILD. The example in Figure 1 shows the interviewee's (everyday) trait-like "stress" level as six while their in-class rating varies from +6 to -10 points. Talk turns are marked with blue diamonds. 
Ducker: Variety, Volatility, Intensity: Understanding Key Characteristics of Individual Learner Differences

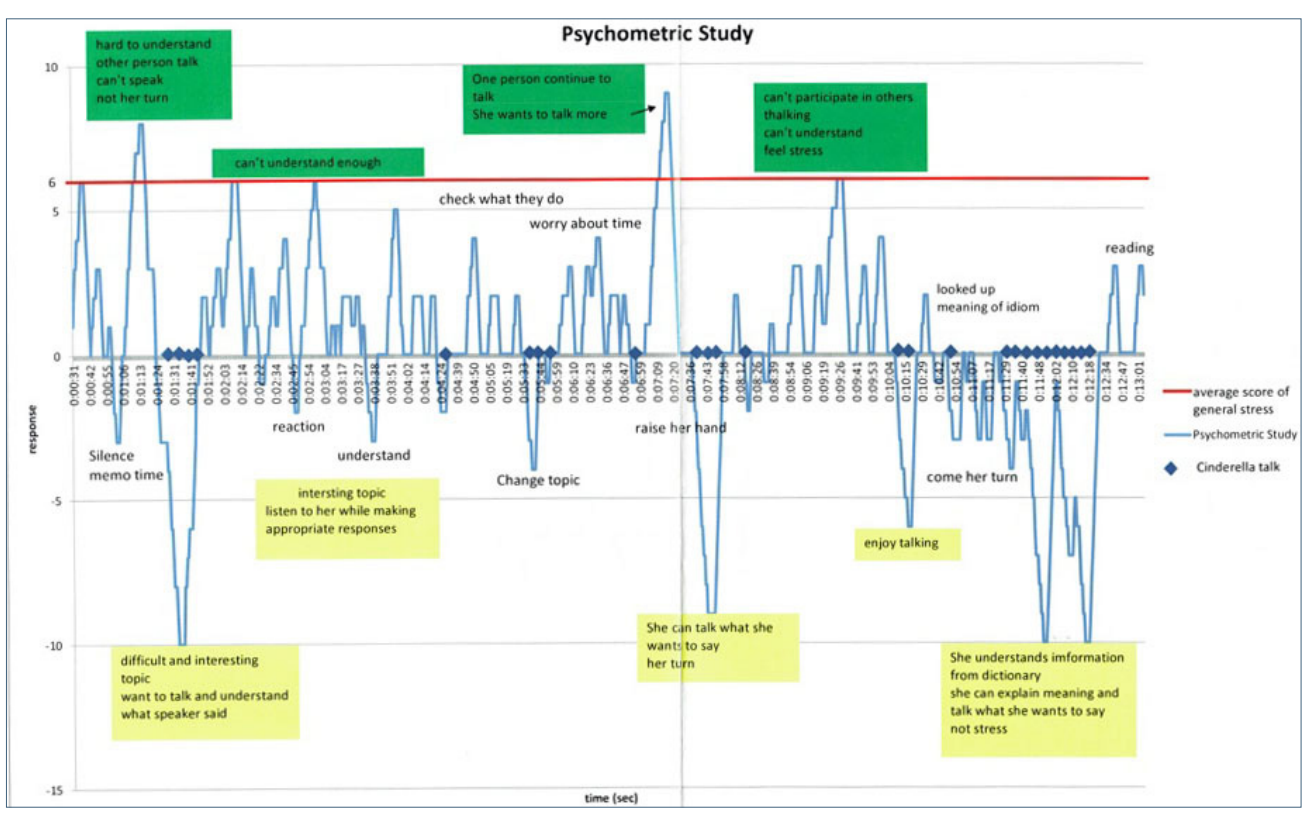

Figure 1. Stress: An idiodynamic poster.

Using pseudonyms to protect identities, students presented their findings as posters in the following class. Three students simultaneously presented in a round robin format until all students had seen each presentation.

Finally, I summarized the findings and key points in a plenary discussion, and any further ambiguities, points of interest, and similarities or differences between learners were clarified. As such, unless stated otherwise, the findings of this study were approved by the students during presentations and at the summary stage.

After the presentation class, students reviewed their activities in weekly journals. Students reported any unclarified points or discrepant items, and I shared further relevant points in the following week's class. Consent to use students' findings and journals, and my classroom notes was received from all participants and the university.
Results

\section{Unexpected Learner Differences}

Students reported a wide range of (sometimes unexpected) ILDs: concentration (number $=1$ ), anger (n1), confidence (n6), happiness (n1), stress (n1), uncertainty (n2), intolerance of uncertainty (n2), anxiety (n1), nervousness (n1), and willingness to communicate (n2).

Selections sometimes needed clarification. I was confused as to why students chose "intolerance of uncertainty" instead of "uncertainty." The reasoning was that only uncertain situations that caused negative feelings were a consideration rather than general uncertainty. Concerning "anger," when the learner could not clearly express $\mathrm{him} /$ herself, frustration led to anger; at other times, anger arose directly when group members did not accept his/her proposed ideas. Peers were somewhat aware of others' internal processes; for example, the ILD "anger" was suggested by the interviewer to the interviewee.

Relevance of ILDs is context dependent. The student who chose "concentration" was influenced by three contextual factors. First, the seminar class was her favourite class and many of her friends participated in the class, so she felt little anxiety. Second, the class took place in $4^{\text {th }}$ and $5^{\text {th }}$ period, so she was tired. Finally, my alternating absence/ presence across two classrooms had a (respectively) relaxing and focusing effect on her concentration.

\section{A Wide Range of Volatility and Stability}

Students commented on the range of volatility (number of changes) in constructs across learners. The following charts show "extremely volatile", "undulating volatility", and "relative stability". Thus, the unpredictable and idiosyncratic nature of ILDs is confirmed.

Figure 2. Concentration: Extremely volatile. 


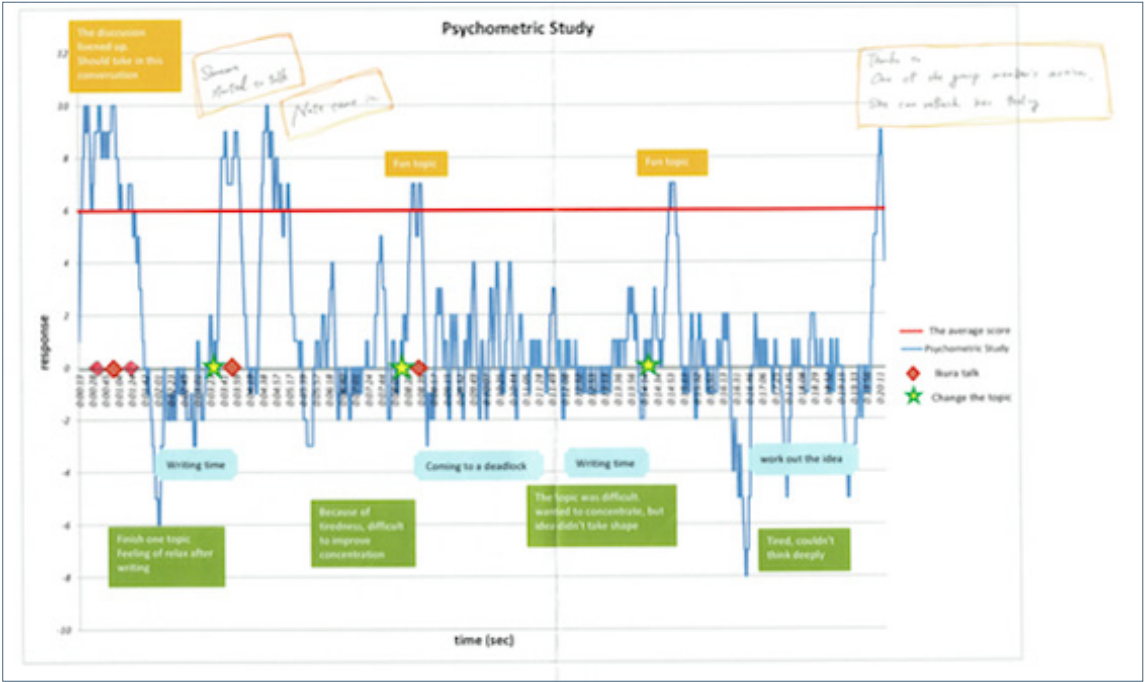

Figure 3. Self-confidence: Undulating volatility.

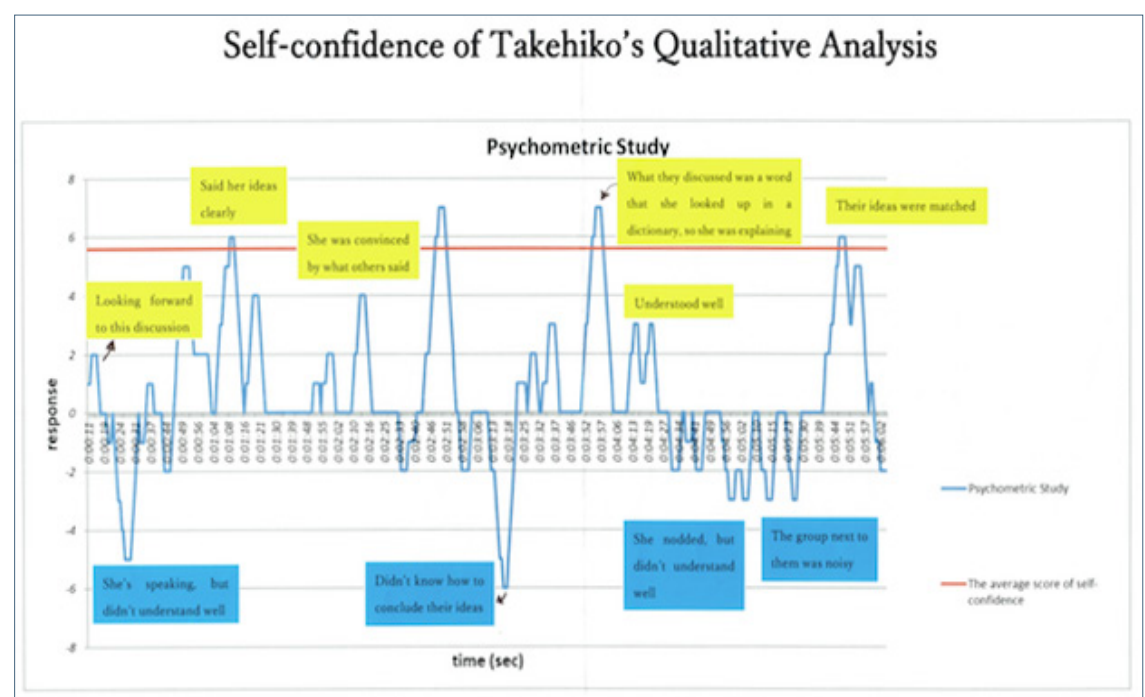

Figure 4. Anger: Relative stability.

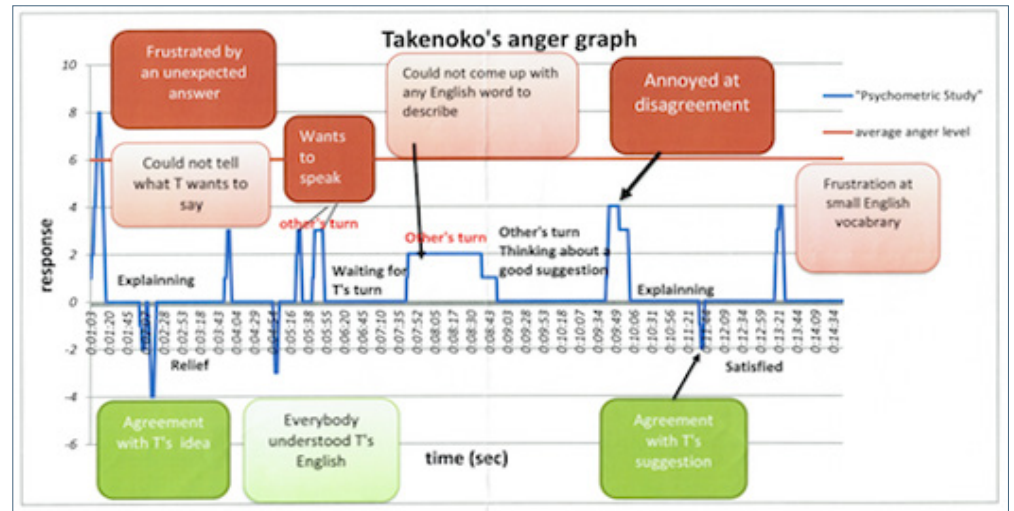

The speed and intensity at which fluctuations occur also varies considerably. Figure 5 is characterized by tall, narrow peaks and troughs, many of which switch between the positive aspect and negative aspect directly; indicating jumps from strongly negative to strongly positive status in a short space in time. One learner described this as "flicking a switch."

Figure 5. Confidence: High intensity fluctuations.

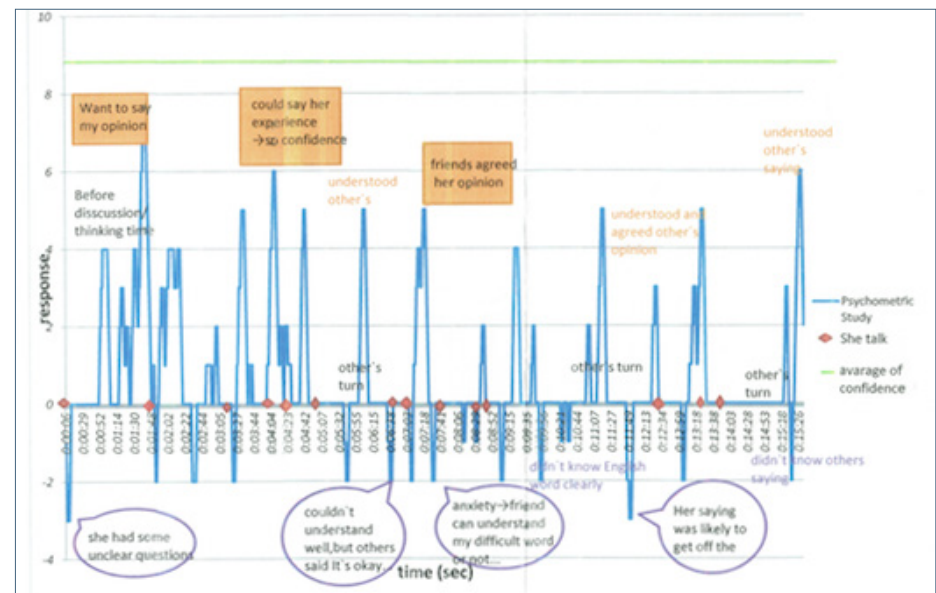

Figure 6 shows similar volatility (number of changes) to Figure 5; however, Figure 6 is 
characterized by small and truncated peaks rising from a larger plateau. This indicates less intense fluctuations over a longer period of time. When larger changes occur, the peaks and troughs increase and decrease in a "stepped" fashion leading to less steep inclines and declines. This indicates more gradual, less intense changes than those shown in Figure 5; this can perhaps be characterized as "ramping up/down the dial."

Figure 6. Confidence (2): Less intense fluctuations.

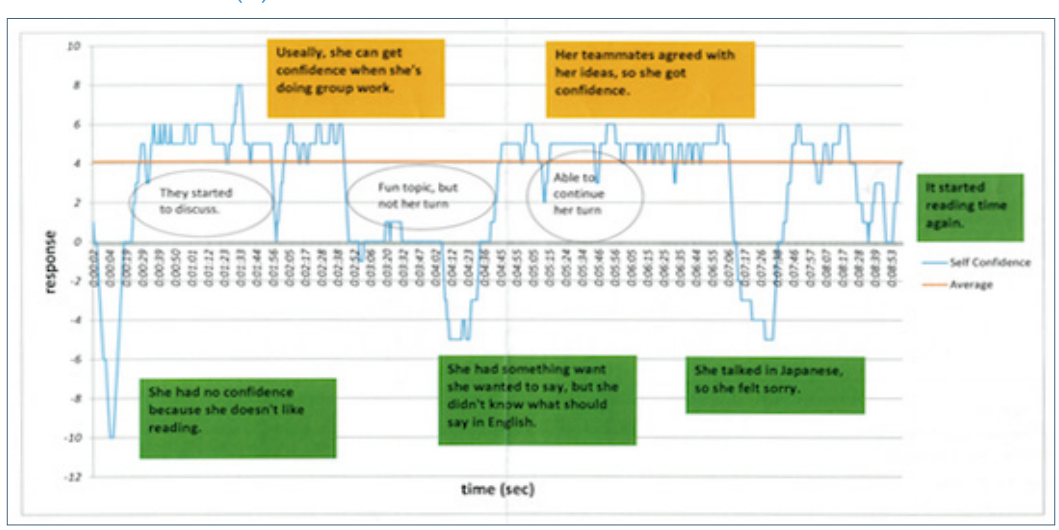

\section{Multiple Coexisting Constructs}

Learners sometimes described influences on their selected ILD by using other constructs. One confidence chart was annotated at multiple points with "happy," whereas one of the "anxiety" charts was annotated with "nervous," "fun," "happy," and "depressed." Moreover, multiple charts were annotated with "confidence" and/or "uncertainty" as a secondary construct. The nature of the relationship between the primary and secondary constructs is unclear, for example, which is cause or effect? Further investigation of this relationship could be achieved in teacher/researcher-learner idiodynamic interviews.

\section{Multi-Causality and Soft Assembly}

Learners described changes to ILDs that reflect the CDST parameters described by Larsen-Freeman (2015) and Macintyre, et al. (2015). Constructs underwent continuous evolution with feedback in the system intrinsically linking changes to prior events and states. Changes were instigated by multiple factors coalescing (multi-causality), while diverging changes to constructs eventuated from similar situations (soft assembly). This is shown in Figure 7 when the learner disagrees with another's opinion; however, nonverbal reassurances from a different member help the interviewee accept the proposal Concurrently, this non-verbal signaling helps spur the subject to re-set her concentration and continue participating. She is able to consequently contribute to the discussion, then feels relief (not disappointment or frustration) when this immediate topic concludes.

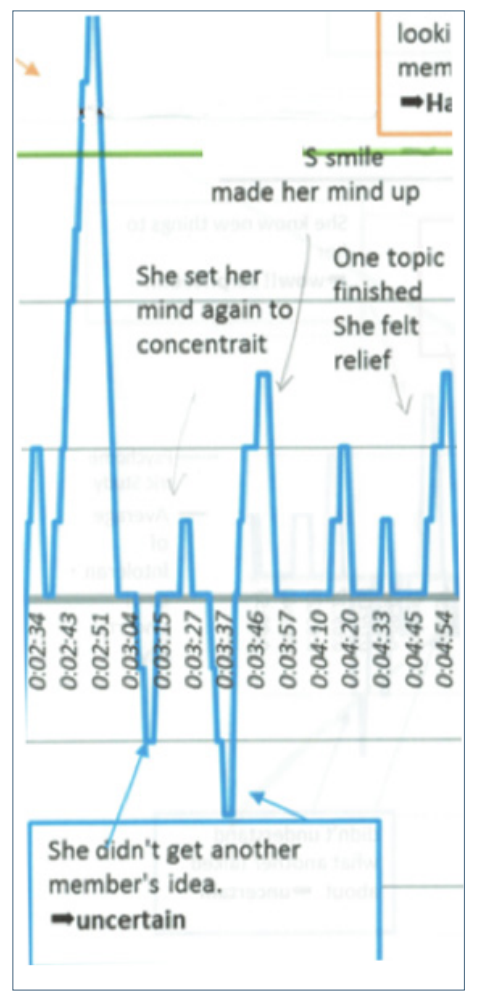

Figure 7. Intolerance of uncertainty: A CDST response to disagreement.

In Figure 8, another example of CDST parameters is shown as the interviewee feels uncertainty concerning the content of her own utterances. A lack of peer-feedback exacerbates this uncertainty, and the ensuing silence is problematic. As peer-feedback breaks the silence, her uncertainty score returns to a positive aspect. Soon after, she struggles to respond to a question, and her uncertainty score returns to the negative 
aspect. Once multiple members respond and ask questions in relation to her ideas, she becomes certain her ideas are appropriate and her score rises sharply to its highest rating. In this case, the combined relief, certainty, and positive feedback react strongly to the previous situation of silence and uncertainty.

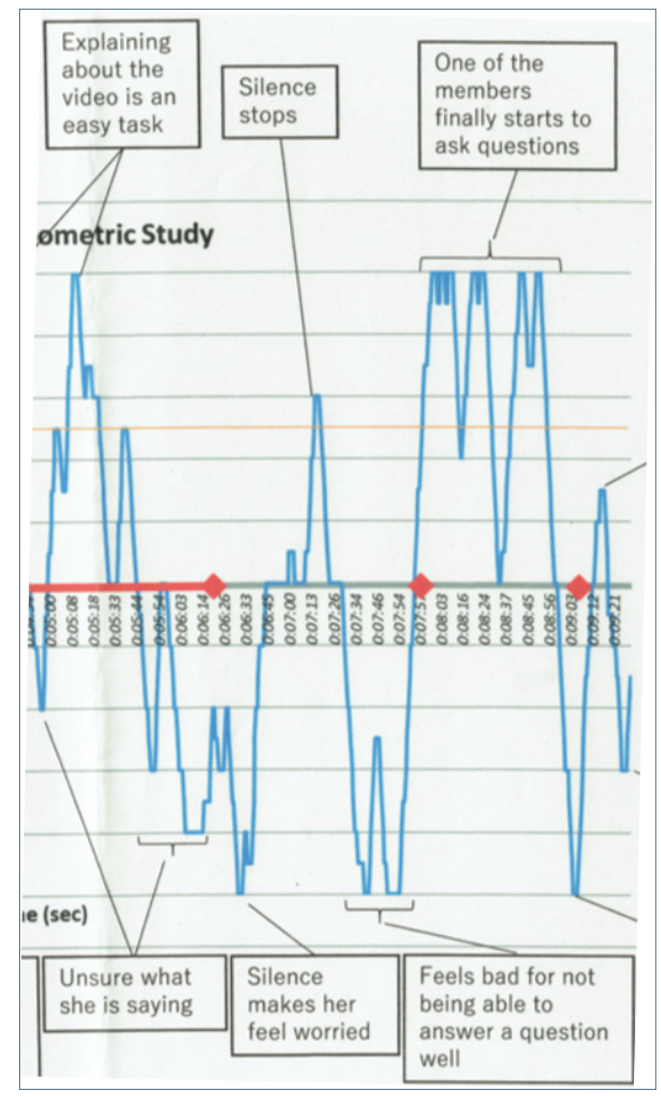

Figure 8. Uncertainty: A CDST response to silence.

\section{Initiators of Change}

During the presentations, the students and I identified five categories of primary factors that initiated change in ILDs. These factors are internal variables (i.e. ILD constructs),

linguistic, topic related, social/environmental, and task stage factors. After class, I counted and described examples of initiators of change that were reported on the posters. In some cases, a primary initiator of change lead to a secondary construct, which then corresponded with changes to ILDs. Examples of sources of change are given in Table 1. The left column, "initiator of change," describes the reason why a change in the ILD rating occurred with examples taken verbatim from charts. The central column indicates secondary constructs. The right-hand column shows changes in ILD ratings.

Table 1. Initiators of Change in ILD Constructs

\begin{tabular}{|c|c|c|}
\hline Initiator of change & Secondary construct & \begin{tabular}{|c|} 
Degree of change to primary \\
ILD construct
\end{tabular} \\
\hline \multicolumn{3}{|c|}{ Factor One: internal variables (skills, interests, ILDs) } \\
\hline doesn't like reading & & confidence -10 \\
\hline looking forward to discussion & & self-confidence +2 \\
\hline $\begin{array}{l}\text { enjoy talking (internalized } \\
\text { feedback) }\end{array}$ & & stress -6 \\
\hline tiredness & & concentration -2 \\
\hline
\end{tabular}

Factor Two: Responses to linguistics issues (comprehension / vocabulary / discourse) if she can / can't understand small English vocabulary discussing a word she had

\section{frustration} able to explain nervous $+6 /-6$ previously looked up in dictionary

Factor Three: Responses to topic related issues (interest, comprehension, knowledge) her opinion was not ready yet, nervous and she had to join new group she learnt a new thing wow!! surprised intolerance of uncertainty -3 her talking was likely to be off the point

she felt strong agreement with her partner's idea (topic confidence) anger +4

self-confidence +7
WM FRONT PAGE
$\checkmark$ PREVIOUS PAGE 
Ducker: Variety, Volatility, Intensity: Understanding Key Characteristics of Individual Learner Differences

\section{Initiator of change}

Secondary construct

Factor Four: Responses to social issues (disagreements, agreements, team-work, atmosphere

got good reactions from the

others

classmate's reaction is

uncertain

talking in Japanese while

classmate was talking in

English

teacher came close

silence

Factor Five: Responses to task stage (beginning, topic change, task progression)

before discussion thinking

time

started reading time again

before start enjoy talking /

laughing

change topic

not her turn

confidence $\&$ happy self-confidence +10

uncertainty -7

\begin{tabular}{l|l} 
depressed & anxiety -6
\end{tabular}

concentration +10

awkward uncertainty -6

confidence $+4,+8$

confidence +4

$+5$

concentration +8

confidence +1

While the student's findings highlight the dynamic, interrelated, and unpredictable ways factors impact ILDs and learners' behaviours, insights into these phenomena may be useful for teachers. For example, the negative impact of uncertainty on specific learners indicates that certain individuals may benefit from teacher-clarification of their ideas during discussions.

\section{Counts of Initiators of Change}

Table 2 shows counts of each initiator of change. Topic-related issues are the most common and internal-factors the least frequently occurring.
Table 2. Counts of Initiators of ILD Change

\begin{tabular}{ccccc}
\hline internal & linguistic & topic-related & social & task stage \\
\hline 15 & 55 & 100 & 75 & 46 \\
\hline
\end{tabular}

Most changes in ILDs are reactions to factors outside of the learners' control. Learners do not choose the stage of the task, social factors arise as a result of peer/ group interactions, and (although topical knowledge is an ILD) topic changes are often instigated or influenced by the teacher or the materials. This points to an important relationship between ILDs and socio-environmental factors.

Furthermore, it indicates that teachers play an important role in preparing learners to respond to environment changes and should create environments that are not overwhelming in terms of topic, social groupings, or task requirements. For example, concerning "concentration," each topic change resulted in a spike in the learner's concentration ratings. Similarly, learners often reported increased anxiety, lack of confidence, and related negative emotions when beginning new topics or tasks.

Accordingly, teachers could provide strategy training to cope with affective difficulties at relevant junctures or preview upcoming task stages.

The second most common causes of changes to ILDs were social issues such as feedback, or lack thereof, from group members. This indicates that ILDs are part of a nested system phenomenon (see Yashima, MacIntyre, \& Ikeda, 2018) in which learners and groups co-adapt to each other throughout a lesson.

The Relationship Between Trait-level and Situated ILD Ratings.

CDST recognizes that ILDs have both trait-like and immediate/situational aspects (Larsen-Freeman, 2015), which can arouse widely divergent behaviours in a learner. For example, a learner may indicate strong trait-like motivation to attend a conversation class, but may display apparently weak situational motivation as they prefer to listen to others rather than actively participate. Understanding such relationships is important for researchers and teachers wishing to use ILD knowledge to develop heuristics and other tools to improve lesson preparations and aid decision-making. However, many ILD studies use quantitative methodology that elicits information about trait-like aspects of ILDs, but are of limited use for teachers as they cannot predict learners' behaviours in specific classroom situations. 
Students' charts reflected this gap between trait-like and immediate aspects of ILDs. In Figure 9, there is a large discrepancy between trait-nervousness (score 9) and the immediate score which only occasionally rises to 6 ; indicating that the learner feels less nervous in the classroom than in their daily life.

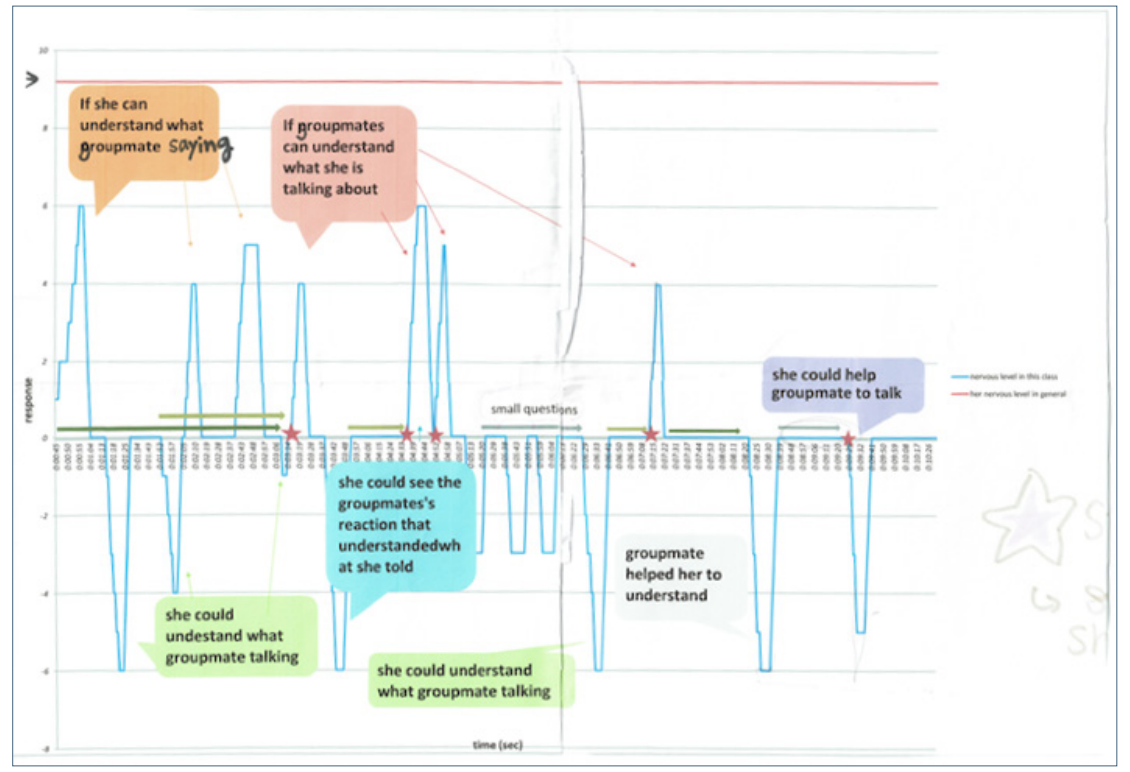

Figure 9. Discrepancy between trait and immediate ratings.

In Figure 10, the opposite phenomenon occurs. The trait-like WTC rating is reported as +5 , but the idiodynamic WTC rating exceeds this on 9 occasions and meets this score a further three times. Both charts seem to reflect positively on the immediate learning situation; thus, understanding factors that led to these phenomena may be useful for future development of good classroom practices.

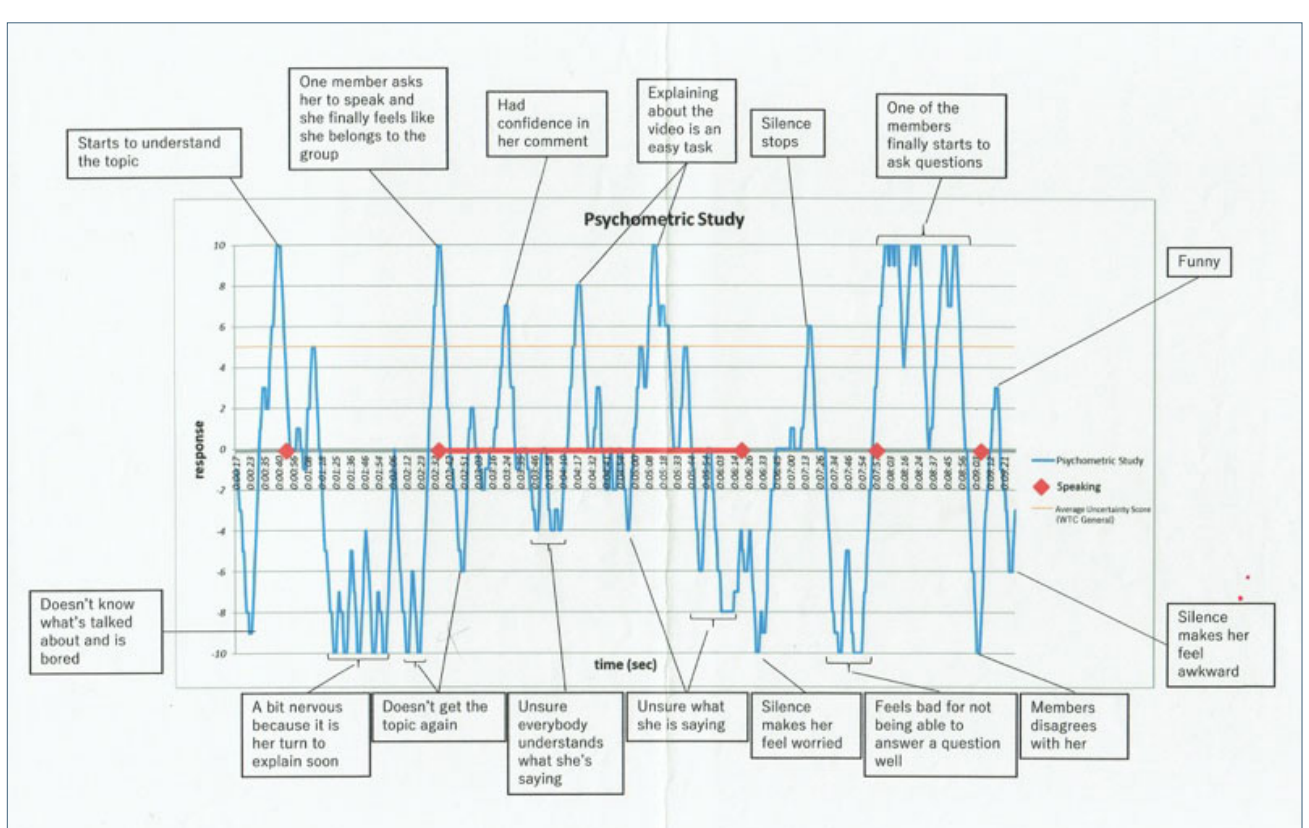

Figure 10. Overlapping trait and immediate ratings.

Implications for Pedagogy and Further Research

This peer-peer approach to studying ILDs uncovered a wide range of topics that may have gone unnoticed by a teacher or researcher. This could help teachers develop a more eclectic approach to classroom management and planning rather than, for example, trying to focus solely on reducing anxiety or increasing motivation.

Teachers need a dual proactive and reactive approach to classroom management; but, with so many variables impacting ILDs, it is impossible to predict how learners will react to any given situation. For example, learners showed negative reactions to linguistic difficulties, perhaps indicating that teachers should make classes easily accessible to all learners; however, task and linguistic challenges provide affordances for development, and learners immediately reported positive ratings when overcoming problems. Detailed analysis of changes to ILDs can help teachers micro-manage such issues. For example, the proximity of the teacher and the introduction of new topics helped stimulate one student's concentration. Similarly, when called upon to speak, some learners frequently 
reported increases in negative constructs. Strategies for controlling negative emotions when their turn arises could be taught to learners.

Social support was also a key issue. Not only is group composition key to providing an environment conducive to learning but it may also be beneficial to explain to learners how to become supportive partners or how to negotiate periods of uncertainty during lessons. Furthermore, learners can be encouraged to view uncertainty and differences of opinion as stimulating affordances for learning rather than as threatening situations.

Suggestions for further research include investigating if, or to what extent, the same learners would choose the same or a different ILD should conditions (topic, teacher, group members) change, while the large variations in volatility and intensity of change in ILDs reported by students are also of interest. For example, what impact does volatility have on learning? Are there underlying causes for this volatility across situations, or is it situation specific? The relationship between trait-like aspects and situational aspects of an ILD construct also warrants investigation as some charts revealed little overlap and other charts large amounts of overlap.

Key ILDs, motivation and aptitude, were not directly discussed, but were present in other ways. For motivation, learners reported interest, fun, excitement, and happiness which are aspects of motivation in that the pursuit of these states induces learners to continue to participate. Aptitude may have manifested itself in how (much) learners could process and discuss new topical information or linguistic items. Teachers may be well served focusing on these immediate aspects, but further research would assert if doing so also carries a long-term beneficial effect.

\section{Conclusion}

Learners acted as co-researchers to investigate the complex dynamic nature of ILDs in the classroom using novel idiodynamic methodology. In addition to learners reporting a wide range of unexpected constructs, such as concentration and anger, the data they elicited from each other also highlighted that ILDs manifest a wide range of volatility and intensity across learners. Five types of factors, internal, linguistic, topic-related, social, and stage-of-the-task, were found to arouse changes in ILD constructs. The findings indicate that ILDs are unpredictable and that teachers need to be sensitive to learners' individuality; however, future research may help to bring some form of predictability that teachers can use to plan activities and develop classroom management techniques. In addition, a deeper understanding of the relationship between trait-like aspects and moment-to-moment aspects of ILDs may help improve classroom management. Finally, by studying the charts that learners create, teachers are reminded of the need to remain sensitive to students' individual needs and the potential benefits of better management of mundane classroom situations, such as topics changes or task stage developments.

\section{Notes}

Contact the author for access to the idiodynamic software used in the study.

\section{Bio Data}

Nathan Ducker is an Assistant Professor at Miyazaki Municipal University, where he teaches EMI classes in intercultural communication and multicultural policy. He has a PhD in applied linguistics from Aston University on the topic of willingness to communicate in the Japanese context. He can be contacted at nathanducker@gmail.com.

\section{References}

Aubrey, S. C. (2010). Influences on Japanese students' willingness to communicate across three different sized EFL classes. The Asian EFL Journal, MA Thesis. Retrieved from http://asian-efljournal.com/thesis/2010/11/01/influences-on-japanese-students-willingness-to-communicateacross-three-different-sized-efl-classes/\#thethe-tabs-1-4

Crawford, M. J. (2015). A study on note taking in EFL listening instruction. In P. Clements, A. Krause, \& H. Brown (Eds.), JALT2014 Conference Proceedings, 416-424. Tokyo: JALT. Retrieved from https://jalt-publications.org/sites/default/files/pdf-article/jalt2014proc_044.pdf

Dörnyei, Z. (2009). The relationship between language aptitude and language learning motivation: Individual differences from a dynamic systems perspective. In E. Macaro (Ed.), The Bloomsbury companion to second language acquisition (pp. 247-267). London, England: Bloomsbury Academic. https://doi.org/10.5040/9781474212397.ch-009

Dörnyei, Z. (2017). Conceptualising learner characteristics in a complex, dynamic world. In L. Ortega, \& Z. H. Han (Eds.), Complexity theory and language development: In celebration of Diane Larsen-Freeman (pp. 79-96). Amsterdam, Netherlands: John Benjamins. https://doi.org/10.1075/1llt.48.05dor

Ellis, R. (2004). Individual differences in second language learning. In A. Davies, \& C. Elder (Eds.), The handbook of applied linguistics (pp. 525-551). Oxon, England: Wiley-Blackwell. https://doi. org/10.1002/9780470757000.ch21

Ellis, R. (2008). The study of second language acquisition ( $2^{\text {nd }}$ ed.). Oxon, England: Oxford University Press. 
Gregersen, T., \& Maclntyre, P. D. (2014). Willingness to communicate. Capitalizing on language learners' individuality: From premise to practice (pp. 211-239). Bristol, England: Multilingual Matters. https://doi.org/10.21832/9781783091218-009

Kang, S. J. (2005). Dynamic emergence of situational willingness to communicate in a second language. System 33(2), 277-292. https://doi.org/10.1016/j.system.2004.10.004

Larsen-Freeman, D. (2015). Ten 'Lessons' from complex dynamic systems theory: What is on offer. In Z. Dörnyei, P. D. Maclntyre, \& A. Henry (Eds.), Motivational dynamics in language learning (pp. 11-19). Bristol, England: Multilingual Matters https://doi.org/10.21832/9781783092574-004

MacIntyre, P.D., \& Doucette, J. (2009). Willingness to communicate and action control. System 38(2), 161-171. https://doi.org/10.1016/j.system.2009.12.013.

MacIntyre, P. D., \& Legatto, J. J. (2011). A dynamic system approach to willingness to communicate: Developing an idiodynamic method to capture rapidly changing affect. Applied Linguistics, 32(2), 149-171. https://doi.org/10.1093/applin/amq037

Maclntyre, P. D., Dörnyei, Z., \& Henry, A. (2015). Conclusion: Hot enough to be cool: The promise of dynamic systems research. In Z. Dörnyei, P. D. Maclntyre, \& A Henry (Eds.), Motivational dynamics in language learning (pp. 419-429). Bristol, England: Multilingual Matters.

https://doi.org/10.21832/9781783092574-025

Matsuoka R. (2015). Willingness to communicate: The effect of conference participation on students' L2 apprehension. In S. Horiguchi, Y. Imoto, \& G. S. Poole (Eds.), Foreign language education in Japan. Critical new literacies: The praxis of English language teaching and learning (PELT) (pp. 133-145). Rotterdam, The Netherlands: Sense Publishers. https://doi.org/10.1007/978-94-6300-325-4_9

Oxford, R. L., \& Amerstorfer, C. M. (2018). Introduction: The state of the art in language learning strategies and individual learner characteristics. In R. L. Oxford, \& C. M. Amerstorfer (Eds.) Language learning strategies and individual learner characteristics: Situating strategy use in diverse contexts (xxiii-xxxiv). London, England: Bloomsbury.

Pawlak, M. (2017). Overview of learner individual differences and their mediating effects on the process and outcome of L2 interaction. In Gurzynski-Weiss (Ed.), Expanding individual difference research in the interaction approach: Investigating learners, instructors, and other interlocutors (pp. 19-40). Amsterdam, Netherlands: John Benjamins. https://doi.org/10.1075/aals.16.02paw

Ranta. L. (2008). Aptitude and good language learners. In C. Griffiths (Ed.), Lessons from good language learners (pp. 142-156). Cambridge, England: Cambridge University Press. https://doi.org/10.1017/CBO9780511497667.014

Robinson, P. (2002). Learning conditions, aptitude complexes and SLA: A framework for research and pedagogy. In P. Robinson (Ed.), Individual differences and instructed language learning (pp.

113-133). Amsterdam: John Benjamins. https://doi.org/10.1075/1llt.2.08rob
Siegel, J. (2015). Exploring listening strategy instruction through action research. London, England: Palgrave MacMillan. https://doi.org/10.1057/9781137521903

Ushioda, E., \& Dörnyei, Z. (2009). Motivation, language identities and the L2 self: A theoretical overview. In Z. Dornyei, \& E. Ushioda (Eds.), Motivation, language identity and the L2 self (pp. 1-8). Bristol, England: Multilingual Matters. https://doi.org/10.21832/9781847691293-002

Yashima, T., MacIntyre, P. D., \& Ikeda, M. (2018). Situated willingness to communicate in an L2: Interplay of individual characteristics and context. Language Teaching Research, 22(1), 115-137. https://doi.org/10.1177/1362168816657851 